\begin{tabular}{|c|c|c|}
\hline \multirow{2}{*}{\multicolumn{3}{|c|}{$\begin{array}{l}\text { ENTOMOLOGICA HUNGARICA } \\
\text { ROVARTANI KÖZLEMÉNYEK }\end{array}$}} \\
\hline & & \\
\hline Volume 80 & 2019 & pp. 293-301 \\
\hline
\end{tabular}

\title{
A new Strymon species from the dry area of the Peruvian Andes (Lepidoptera: Lycaenidae: Eumaeini)
}

\author{
Zsolt BÁLINT ${ }^{1 *} \&$ Ofir TOMER ${ }^{2}$ \\ ${ }^{1}$ Hungarian Natural History Museum, Department of Zoology, \\ H-1088 Budapest, Baross utca 13, Hungary.E-mail: balint.zsolt@nhmus.hu \\ ${ }^{2}$ Israel Lepidopterists'Society, P. O. Box 91, Beit Arye 7194700, Israel. \\ E-mail:ofir.tomer@gmail.com
}

\begin{abstract}
Strymon dubileah sp. n. is described from the dry area of the Peruvian Andes. It was collected in three localities between 2400 and $2900 \mathrm{~m}$ in the department Ancash. Based on genitalia character states the new species is placed in the Strymon ziba (Hewitson, 1868) species group, known hitherto being monotypic. In the literature and in a website the species was documented under the name $S$. abrenholzi Nicolay et Robbins, 2005 and was placed in the Strymon serapio (Godman et Salvin, 1887) species group. Field observations regarding the behaviour of the S. dubileab imagines and the list of local papilionoid fauna are also given. With 15 figures.
\end{abstract}

Key words - diversity, hairstreaks, Neotropical region, species groups, taxonomy

\section{INTRODUCTION}

The Neotropical scrub-hairstreak genus Strymon Hübner, 1818 (type species: Strymon melinus Hübner, 1818, designated by RILEY 1922) was revised by RoBBINS $\&$ Nicolay (2002). Subsequently, more information was published to deepen the insight of Strymon diversity and life history (Nicolay \& RobBins 2005, Vila \& Eastwood 2006, Robbins 2010, Grishin \& Durden 2012, Silva et al. 2016, RAmírez-Fischer et al. 2016, Costa et al. 2018).

One of the faunistically least known regions in the Neotropical realm is the dry areas of the Andes. This was exemplified by the relatively recent discoveries of five Strymon species (NICOLAY \& RoBBins 2005), and by rediscovery of Thecla heodes Druce, 1909 (BÁlint \& Benyamini 2017, BÁlint et al. 2019).

In this paper we report the occurrence of another hitherto undescribed species, collected recently in the dry parts of the Peruvian Andes. Although some specimens were discussed in the literature and the name $S$. abrenholzi Nicolay et

${ }^{*}$ Corresponding author. 
Robbins, 2005 was proposed (NICOLAY \& RoBbins 2005, WARREN et al. 2019), in the light of the recent findings, evidence can be presented for discriminating these specimens as representing a distinct species.

The aims of the present paper are (1) to name and formally describe the species, and (2) to supplement the knowledge related to the butterfly fauna of the Andean dry areas. The material examined for comparative purposes and the methods applied are the same as used for previous papers dealing Strymon (BÁlint \& BENYA Mini 2017, BÁlint et al. 2019, Costa et al. 2018).

Abbreviations of collections $-\mathrm{HNHM}=$ Hungarian Natural History Museum (Budapest, Hungary); MUSM = Museo de Historia Natural, Universidad Nacional Mayor de San Marcos (Lima, Peru).

\section{TAXONOMY}

\section{Strymon dubileah sp. n.}

(Figs 1-6, 9-12)

Type material - Holotype male (Figs 1-2), deposited in the Benyamini collection (Beit Arye; will be deposited in the Steinhardt Museum of Natural History, Tel-Aviv, Israel), set ventrally in moderate condition (tornus in hindwings missing), abdomen dissected (in plastic microvial with glycerine, on the specimen's pin: gen. prep. Bálint no. 1694), originally labelled: "Peru, Ancash, [//] S. entrance to Huaylas [//] 2790m [//] 22/12/2018 [//] Leg. Dubi Benyamini" (white label, printed, "[//]" denotes line break). - Paratypes (nos 1-3): Peru: Ancash, 6km NE of Huaylas, 2420m, 9.XII.2016, leg. Ofir Tomer, 871 (paratype ("allotype") no. 1: female; dissected: gen. prep. Bálint no. 1695; in coll. Benyamini) (Figs 3-4); Peru, Ancash, Amancaes, 2800m, 6.V.1979, (paratype no. 2, male; dissected: Gen. No. 1999, 38M; in coll. MUSM) (Figs 9-10); Peru: Ancash: Caraz, 2400m, 2002 (paratype no. 3: female, in coll. MUSM) (Figs 11-12).

Generic classification and placement - All the species of the tribe Eumaeini possess the following three diagnostic characters: (1) ten forewing veins; (2) "greyhound shaped" male genitalia without a sclerotised juxta; (3) male foretarsus fused, used for walking, and stubby tipped (ELIOT 1973). All Strymon species have setae on the dorsal valva surface modified into anteriorly pointing teeth and most of them have brush organs on the dorsal vinculum (ROBBINs \& Nicolay 2002).

The new species is assigned to the Strymon ziba group because (1) male with a scent patch on the dorsal surface of the forewing, (2) no basal patch of white scales on the ventral surface of the hindwing, (3) aedeagus tip is up-turned with two terminal cornuti, (4) there is no brush-organ (Fig. 5), (5) ductus bursae slightly twisted without a sclerotised loop, and (6) ductus seminalis arises from the sclerotised posterior end of the ductus bursae (Fig. 6). 


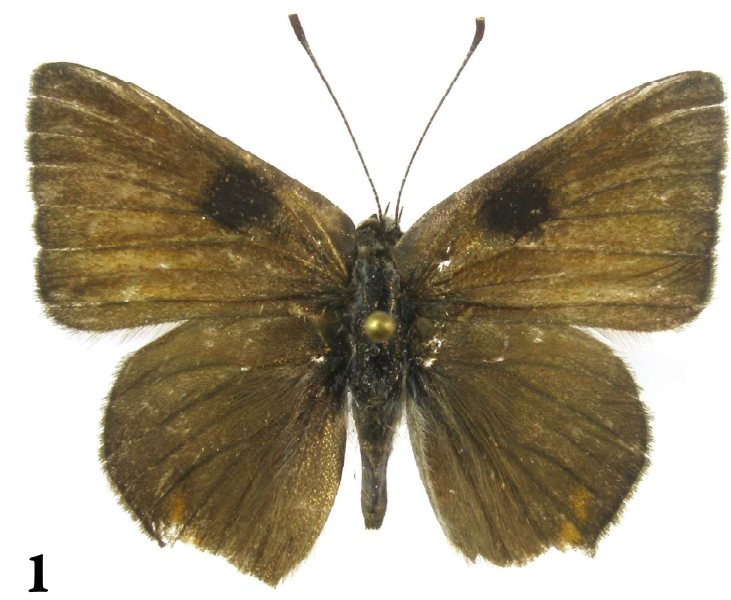

2
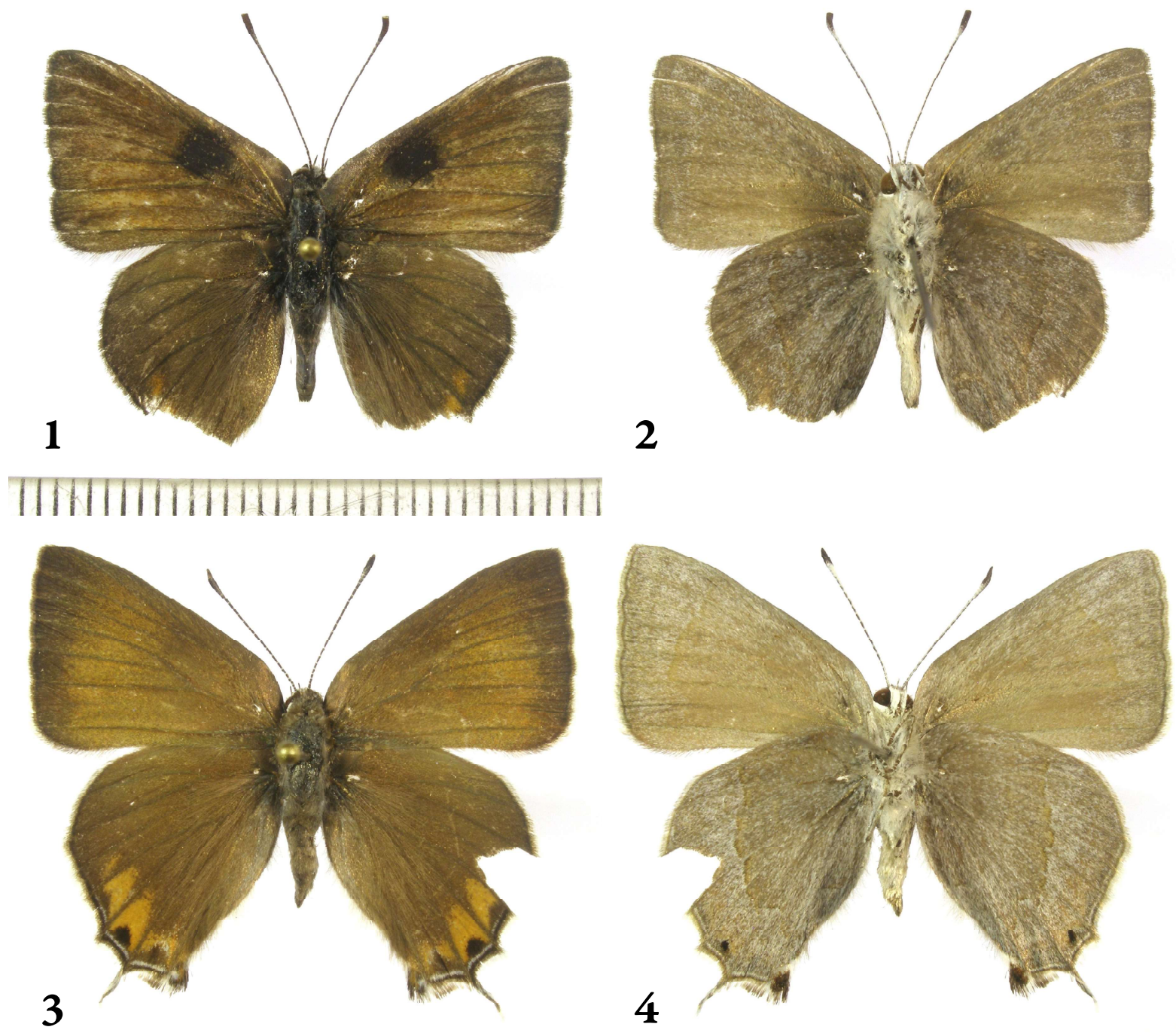

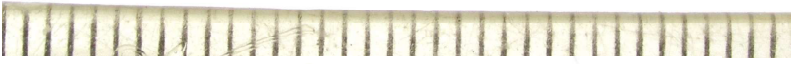
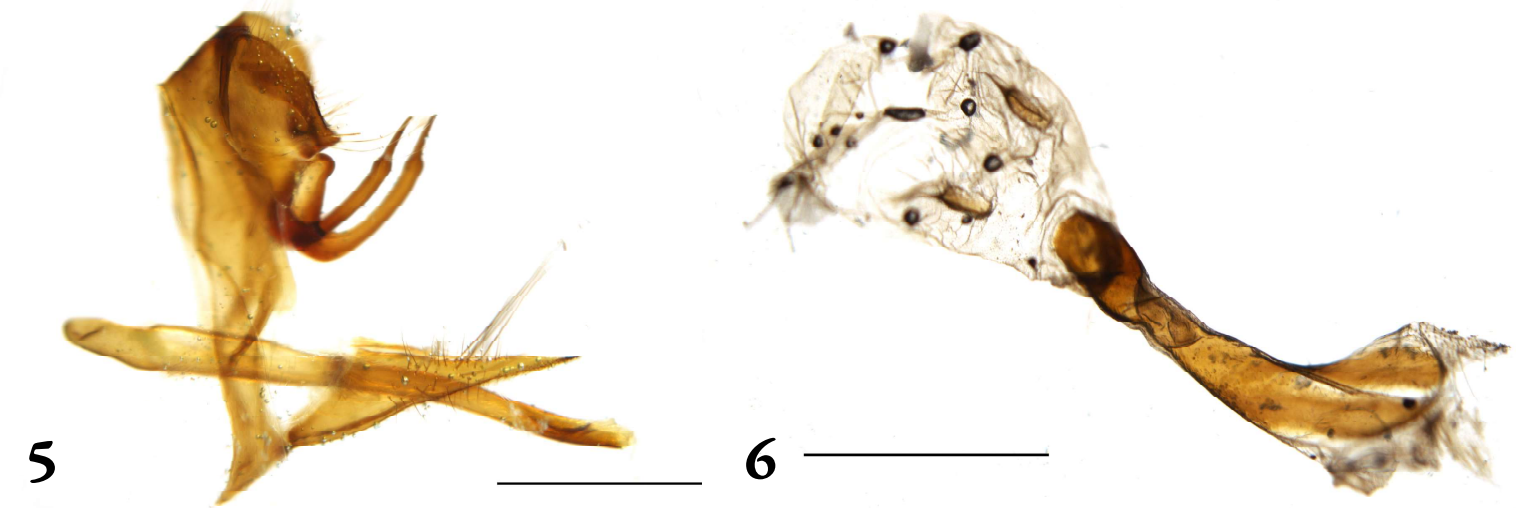

Figs 1-6. Strymon dubileah sp. n. type material: $1=$ holotype, recto, $2=$ idem, verso, $3=$ paratype no. 1 . female, recto, $4=$ idem, verso, $5=$ holotype genitalia in lateral view, $6=$ paratype no. 1 female genitalia in dorsal view. Same scale, bars in $1 \mathrm{~mm}$ for Figs 1-4; scale bar $=0.2 \mathrm{~mm}$ for

Fig. 5, $0.28 \mathrm{~mm}$ for Fig. 6 (photos by Gergely Katona (nos 1-4) and Zsolt Bálint (nos 5-6)) 

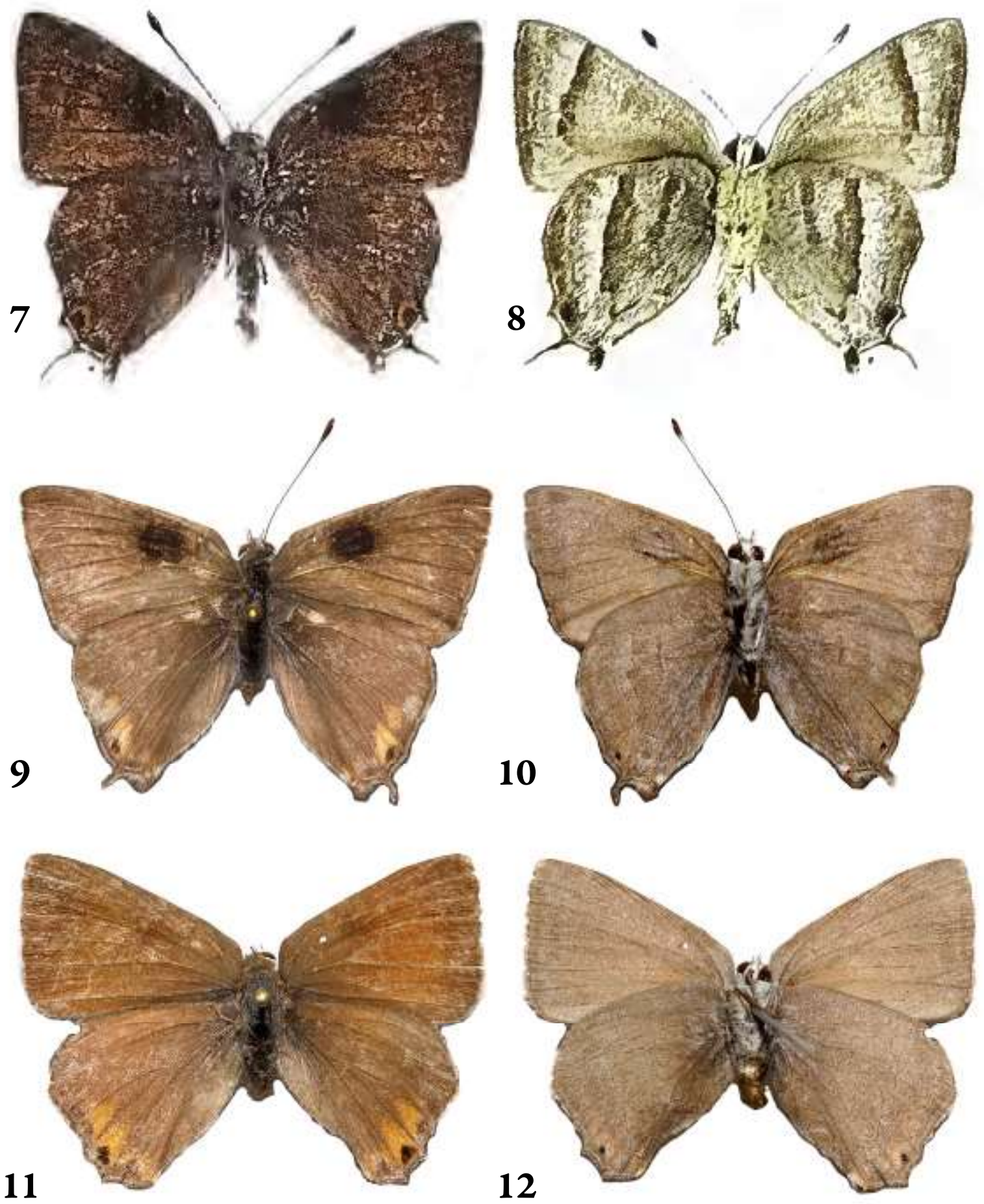

Figs 7-12. Various Strymon documentations: 7-8 = Strymon abrenholzi Nicolay et Robbins, 2005: 7 = holotype, recto, 8 = idem, verso (from Nicolay \& RoBbins 2005); 9-12 = Strymon dubileah sp. n. specimens appearing as $S$. abrenholzi in WARREN et al. (2017): 9 = paratype no. 2 male, recto, $10=$ idem, verso, $11=$ paratype no. 3 female, recto, $12=$ idem, verso (compiled by Gergely Katona) 
Diagnosis - Like in $S$. abrenholzi and $S$. ziba the aedeagus tip is slightly upturned and with terminal cornuti (Fig. 5). All other Strymon have the aedeagus conspicuously down-turned and the cornuti are subterminal; but (1) ventral wing surfaces of $S$. ahrenholzi are patterned by a conspicuous forewing postmedian and hindwing median band, which lack in the new species; and (2) ventral wing surfaces of $S$. ziba are also patterned by conspicuous forewing postmedian and hindwing median row of orange or light red dashes and spots.

Description of male - $(\mathrm{N}=2)$ (Figs 1-2, 5, 9-10) Forewing length $16 \mathrm{~mm}$ (holotype male), apex pointed, outer margin straight. Dorsal wing pattern: forewing dark brown with large ovoid black scent patch filling distal half of discal cell; veins standing out sharply, postmedian area lighter than basal and marginal region; hindwing with orange marginal spots in cells between the vein M3; rudimentary black tail at $\mathrm{Cu} 1$ and long slender white-tipped black tail at $\mathrm{Cu} 2$; fringes in both wings light brown. Ventral wing pattern: forewing pale gray in costal and marginal areas but brown below discalis, orange dashes of postmedian pattern almost invisible, apical and marginal area with lighter scaling. Hindwing pale gray, with faint orange dashes of submedian and postmedian pattern, marginal area darker than medial area. Head: frons with erect scales, primarily white, with a few dark ones intermixed; third segment of labial palps slightly longer than basal two, and covered with closely appressed scales; between antennal bases scales gray. Nudum black and confined to club. Genitalia (Fig. 5): typical of group with slightly upturned aedeagus tip with paired cornuti, no brush organ.

Description of female - $(\mathrm{N}=2)$ (Figs 3-4, 6, 11-12) Forewing length $18 \mathrm{~mm}$ ("allotype"), apex pointed, outer margin straight; otherwise as male, but with more extensive dorsal wing surface orange lunulation. Genitalia (Fig. 6): ductus bursae arises from a sclerotised plate situated on bursa, straight without loop but slightly twisted laterally, ostium widely and deeply divided centrally.

Individual variation - Based on the known specimens $(\mathrm{N}=4)$ there is no significant variation in wing shape, colouration or pattern.

Distribution - Geographical: known only from the Peruvian department Ancash (localities: Amacaes, Caraz, Huaylas) (Fig. 13). Spatial: known from elevations 2400, 2420, 2790 and $2800 \mathrm{~m}$. Temporal: specimens were collected in May and December.

Type locality - Peru, department of Ancash, southern entrance to Huaylas, 2790 m (coordinates: $8^{\circ} 53^{\prime} 4.09^{\prime \prime} S, 77^{\circ} 52^{\prime 2} 20.10^{\prime \prime}$, elevation $2790 \mathrm{~m}$ ) (Figs 13-14).

Bionomics - The male holotype was collected while it was hilltopping on the edge of a ridge along a paved mountain road to Huaylas (Fig. 14). It perched on a bush. The female paratype (no. 1) was recorded on a hill slope (Fig. 15), nectaring on an orange cactus flower (Opuntia sp.). The following Lycaenidae species were collected in the habitats of $S$. dubileah near Huaylas: Eldoradina cyanea (Balletto, 1993), Kurtaria elvira (Johnson, 1992), Leptotes andicola (Godman et Salvin, 1891), Ministrymon azia (Hewitson, 1873), Nabokovia faga (Dognin, 1895), 
S. crambusa (Hewitson, 1874), S. daraba (Hewitson, 1867), S. heodes (Druce, 1909) and S. sapota (Hewitson, 1877).

Etymology - The species is dedicated to the Benyamini family, especially to Dubi and Leah Benyamini, the driving force of lepidopterology in Israel. The name is a Latinised feminine noun arbitrarily formed from the words "Dubi" and "Leah" in weak rhyme with the species-group name of the similar congener Strymon ziba (Hewitson, 1868).

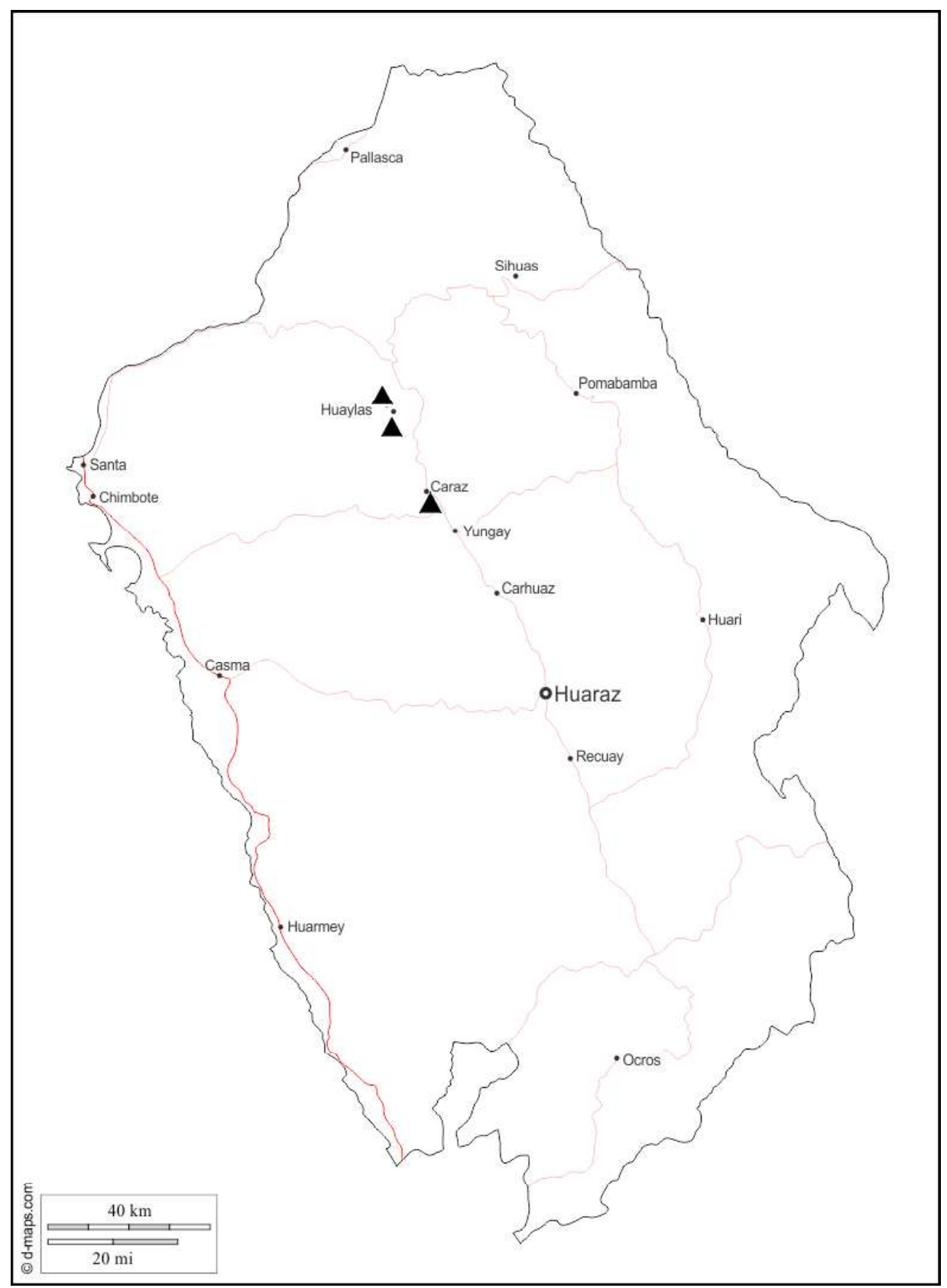

Fig. 13. Known occurrences of Strymon dubileah sp. n. (black triangles) in department of Ancash, Peru 

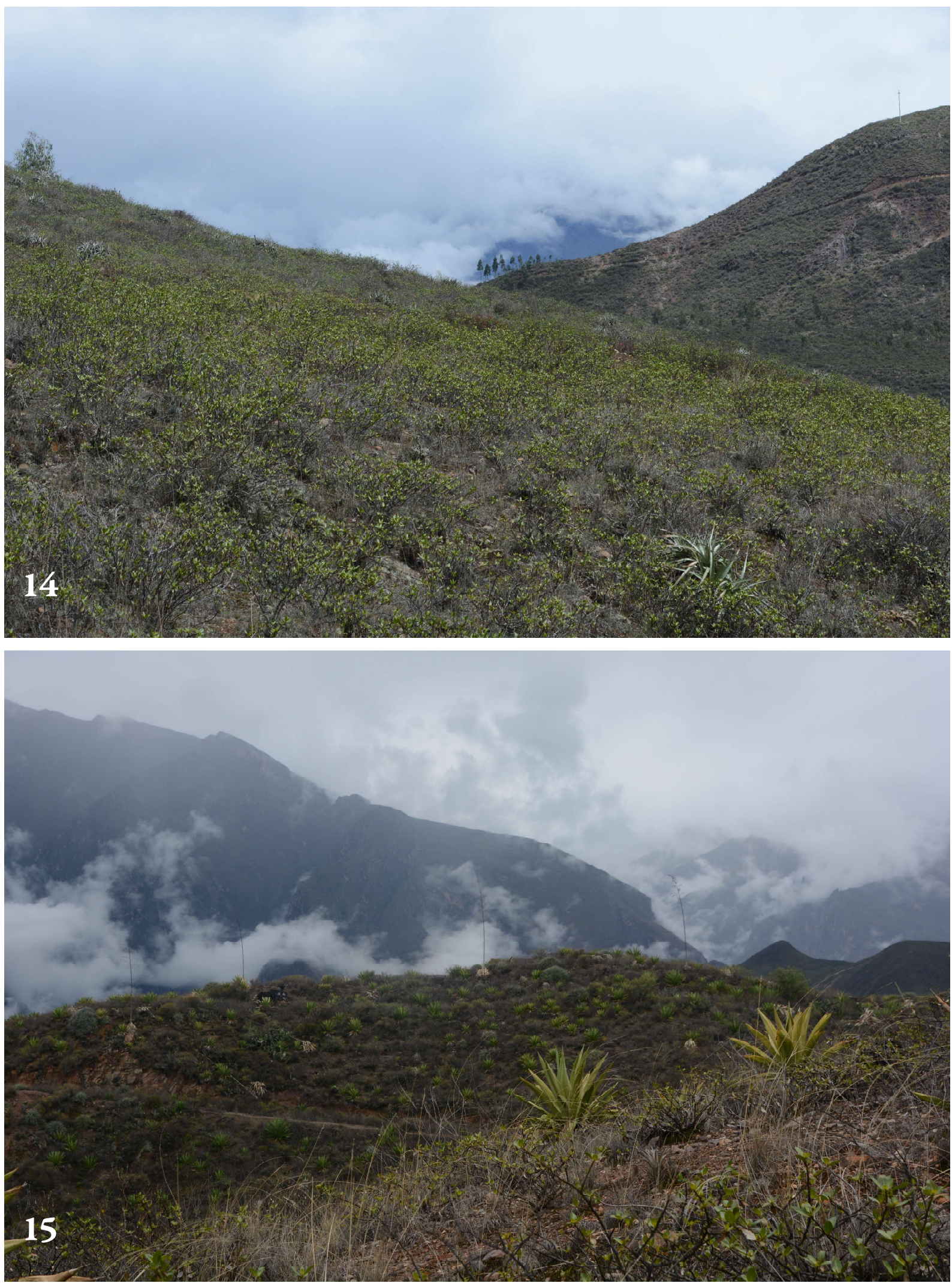

Figs 14-15. Habitats of Strymon dubileah sp. n.: $14=$ the type locality, southern entrance to Huaylas (photo by Dubi Benyamini), $15=6 \mathrm{~km} \mathrm{NE}$ of Huaylas ( $8^{\circ} 50^{\prime} 29.33^{\prime \prime} \mathrm{S}, 77^{\circ} 52^{\prime} 9.24^{\prime \prime} \mathrm{W}$, $2420 \mathrm{~m}$ ), where the paratype no. 1 female was collected (photo by Ofir Tomer) 


\section{DISCUSSION}

\section{Former identifications}

Nicolay \& RobBins (2005), discussing the wing pattern variation of $S$. abrenholzi, mentioned a male specimen from Ancash (Peru), deposited in MUSM. They considered the specimen as conspecific with $S$. abrenholzi, described from southern Ecuador (Figs 7-8) (type locality: "Loja, Loja-Catamayo

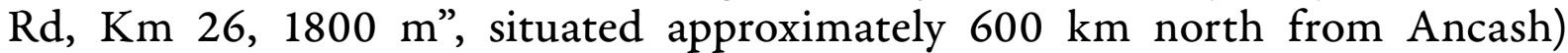
(Fig. 13). This action was based on the undifferentiated genitalia and on the observation that the "ventral wings are markedly rubbed, and its pattern cannot be ascertained". Consequently, the specimen was not designated as paratype of S. abrenholzi. In the website "Butterflies of America" (WARREN et al. 2017) under the name $S$. abrenholzi a male and a female specimen are shown from Ancash (Peru) (Figs 9-12). The male is dissected and most probably, that is the specimen discussed by Nicolay \& RobBins (2005). These two specimens are identical with the recently collected $S$. dubileab specimens; therefore, they are designated as $S$. dubileab paratypes.

\section{Relationships}

We suggest that $S$. ziba and $S$. dubileah are "closest relatives" because they share genitalia and wing characters otherwise unique in the genus (see above Generic classification and placement). The terminal morphology of the aedeagus and the morphology of the ductus bursae especially support this statement (Figs 5-6). Robbins \& Nicolay (2002) formed the S. ziba species group that included a single, but widespread and common titular species. With the inclusion of $S$. dubileab the species group seems to be more diverse. After careful revisionary work some of the taxa considered as synonyms of $S$. ziba in the "Butterflies of America" website (WARREN et al. 2017) may turn to be representing biological species.

Acknowledgements - We thank Dubi Benyamini (Beit Arye, Israel) who collected the holotype. He and his wife Leah hosted the first author many times in their house while he examined Neotropical lycaenids in the Benyamini collection. Thanks are due to Gergely Katona (HNHM) for technical assistance, and to Balázs Tóth (HNHM) and an anonymous reviewer for their notes on the manuscript. 


\section{REFERENCES}

BÁLInt Zs. \& Benyamini D. 2017: Corrected synonymies: the identities of Strymon bicolor (Philippi, 1859) and Strymon heodes (Druce, 1909) (Lepidoptera: Lycaenidae). - Opuscula Zoologica Instituti Zoosystematici et Oecologici Universitatis Budapestinensis 48(1): 61-69.

https://doi.org/10.18348/opzool.2017.1.61

Bálint Zs., Cerdeña Gutiérrez J., Boyer P., Florczyk K. \& Pyrcz T. W. 2019: Notes on the identity of the male paralectotype of Thecla heodes and description of a new species: Strymon cryptodes sp. nov. from northern Peru (Lepidoptera: Lycaenidae). - Opuscula Zoologica Instituti Zoosystematici et Oecologici Universitatis Budapestinensis 50(1): 23-29.

https://doi.org/10.18348/opzool.2019.1.23

Costa M., Viloria Á. L., Attal S., Benmesbah M., Neild A. F. E. \& BÁlint Zs. 2018: Lepidoptera from the Pantepui. Part V. New Lycaenidae (Theclinae: Eumaeini). - Opuscula Zoologica Instituti Zoosystematici et Oecologici Universitatis Budapestinensis 49(2): 163-179. https://doi.org/10.18348/opzool.2018.2.163

Eliot J. N. 1973: The Higher Classification of the Lycaenidae (Lepidoptera): A Tentative Arrangement. - Bulletin of the British Museum (Natural History), Entomology 28(6): 371-505. https://doi.org/10.5962/bhl.part.11171

Grishin N. V. \& DURden CH. J. 2012: New bromeliad-feeding Strymon species from the Big Bend National Park, Texas, USA and its vicinity (Lycaenidae: Theclinae). - Journal of the Lepidopterists' Society 66(2): 81-110. https://doi.org/10.18473/lepi.v66i2.a3

Nicolay S. S. \& Robbins R. K. 2005: Five new dry-area South American Strymon species (Lycaenidae: Theclinae) and their biogeographic significance. - Journal of Research on the Lepidoptera 38: 35-49.

RAmírez-Fischer F. J., Benyamini D. \& Vargas H. A. 2016: An endangered hemiparasitic shrub is the only host plant of the little-known Neotropical hairstreak Strymon flavaria (Lepidoptera: Lycaenidae) in the arid Andes. - Journal of Insect Conservation 20(5): 923-928. https://doi.org/10.1007/s10841-016-9919-1

RILEY N D. 1922: Notes on the generic names of Indian Theclinae and Amblypodiinae (Lep. Rhop.). Journal of the Bombay Natural History 28: 465-473.

Robisns R. K. 2010: The "upside down" systematics of hairstreak butterflies (Lycaenidae) that eat pineapple and other Bromeliaceae. - Studies on neotropical Fauna and Environment 45(1): 21-37. https://doi.org/10.1080/01650521003751712

Robbins R. K. \& Nicolay S. S. 2002: An overview of Strymon Hübner (Lycaenidae: Theclinae: Eumaeini). - Journal of the Lepidopterists'Society 55(3): 85-100.

Silva N. A. P. DA, LePeSQueur C., Souza A. R. \& Morais H.C. De 2016: Biology of the immature stages of Strymon crambusa (Lycaenidae, Theclinae) on Oxalidaceae. - Revista brasileira de Entomologia 60(1): 68-72.https://doi.org/10.1016/j.rbe.2015.11.003

Vila R. \& EASTwOod R. 2006: Extrafloral nectar feeding by Strymon jacqueline Nicolay \& Robbins, 2005 (Lepidoptera: Lycaenidae: Eumaeini). - Revista peruana de Biología 13(1): 125-128. https://doi.org/10.15381/rpb.v13i1.1775

Warren A. D., Davis K. J., Stangeland E. M., Pelham J. P., Willmott K. R: \& Grishin N. V. 2017: Illustrated Lists of American Butterflies. http://www.butterfliesofamerica.com/ [Accessed 1 December 2019.] 